Intersections

Canadian Journal of Music

Revue canadienne de musique
Intersections

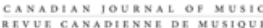

\title{
Mytheme and Motif: Lévi-Strauss and Wagner
}

\section{John Leavitt}

Volume 30, numéro 1, 2010

URI : https://id.erudit.org/iderudit/1003501ar

DOI : https://doi.org/10.7202/1003501ar

Aller au sommaire du numéro

Éditeur(s)

Canadian University Music Society / Société de musique des universités canadiennes

ISSN

1911-0146 (imprimé)

1918-512X (numérique)

Découvrir la revue

Citer cet article

Leavitt, J. (2010). Mytheme and Motif: Lévi-Strauss and Wagner. Intersections, 30(1), 95-116. https://doi.org/10.7202/1003501ar

\section{Résumé de l'article}

Claude Lévi-Strauss voyait en Richard Wagner « le père irrécusable de l'analyse structurale des mythes ». Partant de cette évaluation, cet article compare l'analyse des mythes de Lévi-Strauss à la construction des mythes de Wagner, faisant valoir que l'une éclaire, précise et enrichit potentiellement l'autre.
All Rights Reserved (C Canadian University Music Society / Société de musique des universités canadiennes, 2011
Ce document est protégé par la loi sur le droit d'auteur. L’utilisation des services d'Érudit (y compris la reproduction) est assujettie à sa politique d'utilisation que vous pouvez consulter en ligne.

https://apropos.erudit.org/fr/usagers/politique-dutilisation/ 


\title{
MYTHEME AND MOTIF: LÉVI-STRAUSS AND WAGNER ${ }^{1}$
}

\author{
John Leavitt
}

This paper results from a question put to me by Pierre Maranda, an anthropologist and structuralist theorist, during a panel in honour of the Lévi-Strauss centenary at the May 2008 meeting of the Canadian Anthropology Society. His question-apparently à propos de rien, since my talk had been about LéviStrauss and poetics-was whether I understood why Lévi-Strauss loved (aimait) Wagner. Maranda was a personal friend of Lévi-Strauss, but it had always been a mystery to him. As it happened, I felt I had a pretty clear idea of why LéviStrauss loved Wagner, one that seemed so obvious that I assumed that everyone already knew it. As I came to realize, this was not the case.

I begin this paper by addressing the issue of why Lévi-Strauss should have been fond of Wagner. Next, I briefly present what I take to be the symmetry in the methods used by the two: Lévi-Strauss in analyzing already-existing myths into mythemes; Wagner in constructing a mythic work of art using motifs. I follow this discussion with a brief exemplification of some Wagnerian motifs. In the remainder of the paper, I look at some ways in which considering the methods of Lévi-Strauss and Wagner helps to understand both of them. ${ }^{2}$

\section{LÉVI-STRAUSS AS WAgNERIAN}

Why should it surprise anyone that Lévi-Strauss was fond of Wagner? We associate both myths and music with Lévi-Strauss; but Wagner's name is arguably the first to come to mind when this relationship is placed in the context of classical music. Yet there are many music lovers who do not like Wagner; for some, their dislike is due to the nature of the music itself, which they find heavy, pompous, and melodramatic; others find his operas painfully long and boring, sometimes silly, and all too easy to parody. Consider,

1 I would like to thank Robert Crépeau, Nathalie Fernando, John Galaty, Lori Harreman, Edward Jurkowski, Charles Malamoud, Pierre Maranda, Annie Montaut, Jean-Jacques Nattiez, and two anonymous readers for their very helpful suggestions during the composition of this article.

2 My training is in anthropology, and, as I fear will be evident, I am not any kind of musicologist, ethno- or other. It will thus necessarily be the case that my treatment of motif and Wagner will be less developed and more ad hoc than that of myth and Lévi-Strauss. In addition, this discussion will be limited to the Ring cycle, which is where I see the parallels between Wagner and Lévi-Strauss most clearly. Unattributed translations are my own. 
for instance, Mark Twain's famous aphorism that Wagner's operas would be wonderful if it were not for the singing. ${ }^{3}$

Equally important for many, particularly for those who lived through the rise of fascism and the Second World War, are both Wagner's explicit antiSemitism and popularity with the Nazis. For these people, Wagner's music is the score for triumphal fascism; the association is so powerful that it overshadows any pleasure they might take in the music itself.

Yet Lévi-Strauss was an anti-racist and anti-fascist Jew, indeed a refugee during the war. ${ }^{4}$ As a scholar he is known particularly for the delicacy and elegance of his analyses and for his hostility to sentimentalism. One would expect him to be anything but Romantic and Germanophilic; yet, perhaps ironically, he was a devoted Wagnerian.

Among the reasons for Lévi-Strauss's fondness of Wagner, the first we should identify is simple nostalgia. Lévi-Strauss tells us that in his youth he revered "that God Richard Wagner" (Lévi-Strauss [1964] 1969, 15). Beyond the general cult of Wagner centred at Bayreuth, at the beginning of the twentieth century many cultured families in France, including Jewish families (think of Proust), 5 saw Wagner as an artistic hero. ${ }^{6}$

This "religion" had room for a progressive wing, which not only saw Wagner's music as a stylistic revolution but read his operas as promoting a universal revolutionary message. This perspective is typified in the socialist George Bernard Shaw's The Perfect Wagnerite, first published in 1898, which interprets the Ring of the Nibelung as a critique of industrial capitalism.

Yet I believe there to be another, and arguably more significant, reason behind Lévi-Strauss's Wagnerism. Lévi-Strauss articulates it by writing that "we must recognize in Wagner the undeniable father of the structural analysis of myths" $(1964,23) .7$ But in what way? We are used to recognizing some familiar figures as precursors of Lévi-Strauss's methods: Marx, Saussure, Boas, Jakobson, Mauss ... but Wagner?

To understand Lévi-Strauss's perspective on Wagner, we need to lay out some of the methodological principles that he proposes for the analysis of myths.

\section{LÉVI-STRAUSS'S POSTERIOR ANALYTIC}

A myth is a narrative, unfolding in narrative time. The first step in structural analysis is to cut the myth up into minimal narrative units, each of which

3 Mark Twain attended Parsifal at Bayreuth: "It does seem to me that nothing can make a Wagner opera absolutely perfect and satisfactory to the untutored but to leave out the vocal parts. I wish I could see a Wagner opera done in pantomime .... The first act of the three occupied two hours, and I enjoyed that in spite of the singing" (Twain [1891] 1917, 183).

4 Because of his Jewish ancestry, Lévi-Strauss lost his French citizenship in 1940. He escaped Vichy France, reaching New York in 1941, where he spent the war years, remaining in the United States for some years thereafter.

5 See Nattiez (1984) 1989.

6 On the Wagnerian vogue in France, see Coeuroy 1965.

7 My translation. The standard English version puts it more weakly: "undeniable originator" ([1964] 1969, 15) in place of père irrécusable. 
embodies a relationship that, in turn, can be represented by a sentence. "The dwarf Alberich curses love" would be one such relationship; "The hero Siegfried slays the dragon Fafner" is another. We can represent each of these minimal units, images, or incidents, in many ways: by a vast array of different sentences, in a variety of poetic or prosaic forms, or they can be put into images, into song, drama, opera, film-or even into comic strips. What matters at this level, says Lévi-Strauss, is not the form of the message, but, in his own words, "the story which it tells" (Lévi-Strauss 1963, 206). ${ }^{8}$

How can we distinguish these basic building blocks of myths from the not particularly mythical relationships that can be represented in any sentence, which may or may not make up part of any story? Lévi-Strauss argues that what is distinctive about myth-units is that they echo each other along the narrative chain, creating a network of associations that crosscut the line of the story. He proposes analyzing myths by identifying such semantic echoes and grouping them into packets or columns of relations. In a myth or a myth cycle, for instance, there might be a series of characters who kill dragons or other monsters; the repetition of the theme indicates its importance. By comparing such packets among themselves it should be possible to uncover the true life of myths, which, in Lévi-Strauss's view, think out abstractions in the form of concrete presentations in what he calls "the science of the concrete." 9 In his work during the 1950s, the abstractions that are carried in myths are presumed to be those that are problematic for the society that creates the myths, and the analytical goal is to uncover the social or ideological contradictions at the heart of the mythmaking in each case. ${ }^{10}$ In his subsequent writings, LéviStrauss concentrated primarily on the transformations that take place as these structures of relations cross social, cultural, linguistic, or semiotic boundaries (e.g., when a myth told by one people is echoed or inverted by a ritual among its neighbours).

This analytic method presupposes a theory of synthesis. ${ }^{11}$ In generation after generation, tellers of tales have largely unconsciously elaborated stories that refer obliquely to great themes that are sensitive for their own society, multiplying contrasting images and relations to which they allude without facing them directly. The recognition, even unconscious, of such implicit patterns would be the source of the intellectual and aesthetic satisfaction that myths offer to their receivers and would explain both their preservation and their transformation through time.

8 Given the importance of specific wording for the discussion here, I refer to three versions of Lévi-Strauss's essay "The Structural Study of Myth": the original composed in English (1955); LéviStrauss's longer French reworking as it appears in his collection Anthropologie structurale (1958); and the English-language translation of this volume (1963).

9 This is the title of the first chapter of Lévi-Strauss's most general work on human thinking, $\mathrm{La}$ pensée sauvage (1962).

10 The most extensive such study, dealing with a myth from the Tsimshian of British Columbia, is Lévi-Strauss (1958) 1973.

11 This distinction recalls that proposed by Paul Friedrich between analytic ethnopoetics, practised by scholars seeking to understand, and synthetic ethnopoetics, practised by poets seeking to make poems (Friedrich 2006). 
Lévi-Strauss sees the same process taking place in the apperception of music: "In this way," he says, "there is a sort of continual reconstruction taking place in the mind of the person who is listening either to music or a myth. This is more than a mere similarity: it is as if in the invention of musical forms, music had merely rediscovered structures that already existed on the level of myths" (Lévi-Strauss 1993, 43). Here Lévi-Strauss is referring particularly to Romantic and post-Romantic music, which appeared in the West at the same time as the loss of relevance of the great religions and their myths, and which, as it were, fulfils their former functions.

There are two points of note. First, for Lévi-Strauss the mythic quality of the images and events of the story and the relationships that form its successive units are not to be found in their capacity to convey information, but in their power of association. They are "relational objects." We might think here of the difference between Freud's primary and secondary processes; but the obvious parallel, and probably the source of this conception, is the idea of the poetic function elaborated by Lévi-Strauss's friend, mentor, and collaborator Roman Jakobson (see, for instance, Jakobson 1960). For Jakobson, the poetic function is actualized through the recognition of resonances among sounds, words, and grammatical structures along the chain of discourse-resonances that are actualized through partial repetition and parallelism, processes that have no role in language outside of the poetic function. ${ }^{12}$

For Lévi-Strauss, such resonances connect the represented images and relations with each other; his analyses propose a poetics of the narrated image. What makes mythic units different from other sentence-level relations is that they rhyme, as it were: the distinctive feature of what we could call the mythic function is semantic rhyme. ${ }^{13}$

In second place, these echoes and resonances among mythic units, as for Jakobson those among phonemes, words, or grammatical structures, crosscut the narrative chain, break up narrative time, and allow access to underlying structures that exist, one might say, outside of time. In myth, an incident evokes antecedent incidents and anticipates, or indeed incites, subsequent developments. The addressee of the myth, who, we must presume, shares knowledge and expectations with the teller, simultaneously follows along the narrative line and floats above (or below) it. For Lévi-Strauss, both music and mythology are "machines for the suppression of time." 14 That "the poetic function projects the principle of equivalence from the axis of selection into the axis of combination" (Jakobson 1960, 358) means that in an utterance in which the poetic function is dominant, the echoes and resonances among sounds, words, measures,

12 "Measure of sequences is a device which, outside of the poetic function, finds no application in language" (Jakobson 1960, 358).

13 Similarly, Carolyn Abbate observes that Wotan's monologue in Die Walküre, act 2, scene 2, is semantically strophic: "It is not strophic in the conventional sense, not divided into verses with repeating rhyme schemes. But it is strophic semantically, strophic in that the master trope is repeated many times, strophic in its asymmetrical sonorous recurrences" (Abbate 1991, 175).

14 Lévi-Strauss 1964, 24. The English translation of this passage takes what I find to be surprising liberties: it renders machines pour supprimer le temps as "instruments for the obliteration of time" ([1964] 1969], 16). As anyone with any exposure to Freud knows, to suppress hardly means to obliterate. 
and syntactic patterns create a network of linkages that cut across the line of the text: the poetic, in other words, is as much a machine for the suppression of time as are myth and music.

\section{WAGNER'S PRIOR SYNTHETIC}

If we compare Lévi-Strauss's analytical method to Wagner's system of composition by leitmotif ("leading motifs"), the parallels are evident (according to Carl Dahlhaus [1986] 1988, 460, they are almost "too simple to deserve general comment"). Wagner's goal was not to analyze or to understand, but to construct something. ${ }^{15} \mathrm{He}$ began with a narrative that he composed himself on the basis of his readings in Norse mythology and German legends. In anticipation of Lévi-Strauss, Wagner maintains that what makes a narrative effective are the semantic echoes among the events, images, and characters, which make it possible to present and discuss abstract ideas in concrete form.

Wagner's innovation was to develop a system of opera composition based no longer on well-defined sections of aria and recitative, but on the construction of a single total work - and in the case of the Ring of the Nibelung, a monumental work-by "weaving a fabric of themes and motifs" (Mann [1963] 1985, 188), each of which was linked to a character, image, or event. These Grundthemen, now usually called leitmotifs, take the form of mini-melodies, "a musical cell that returns regularly and that is invested with a particular meaning (descriptive, philosophic...)," which can be as straightforward as "a simple chord or a simple rhythmic pattern" (Godefroid 1988, 96). Leitmotifs keep coming back, recycling over and over again, through the sixteen hours of the Ring, and are meant to serve, alongside the images and events on the stage, to guide and direct the associations and emotional reactions of the audience. ${ }^{16}$ It is important to note that leitmotifs are not mere tags, but provokers of association and implication; as Lévi-Strauss himself suggested, "sometimes, the recurrence of a motif connects different, not obviously related episodes by pointing out hidden parallels or oppositions that nevertheless underlie the plot" ([1983] 1985, 236).

Wagner himself is explicit about his synthetic method of composition in his 1851 book Opera and Drama, a work that dates from the early compositional period of the Ring. Certain pages of the book sound positively Lévi-Straussian in character.

- Motifs can be thought of as existing on the level of the sentence, yet they are "no mere 'sentences' [Sentenzen], but plastic moments-of-Feeling [plastische Gefühlsmomenten]" (Wagner 1851 [1893], 347). ${ }^{17}$

- Wagner insists on the trans-temporal character of the motifs, which crosscut the line of the narrative, tying together past and future, or, to cite the passionate Wagnerian T.S. Eliot, "mixing memory and desire." The key words here are Ahnung, "intimation or presentiment," and Erinnerung, "memory": Wagner writes of ahnungsvolle Erinnerungen,

15 On the construction of the Ring, see Dahlhaus (1971) 1979; Nattiez 1983, part 1; and Abbate 1991, 157-61; on Wagner's sources, see Cord 1990, 125-32.

16 On leitmotifs, see, for instance, Whittall 2006, Grey 2008, Thorau 2009.

17 They are thus provokers of associations. 
memories that are full of presentiment, of "these melodic moments in which we remember a presentiment, as they transform memory into presentiment for us"-in denen wir uns der Ahnung erinnern, während sie uns die Erinnerung zur Ahnung machen. ${ }^{18}$ These can, then, be interpreted as the gears in machines for the suppression of time.

- There is a major difference between the two authors, one in which, in my view, Wagner is in advance of Lévi-Strauss. ${ }^{19}$ For Wagner the manipulation of motifs has effects that are not simply intellectual: it concomitantly focuses and directs specifically emotional associations. The motif should "embody such a power and directness of expression that the emotion concerned would be recalled when the motif itself returned, even if action or text no longer alluded directly to its original associations" (Whittall 2006, 154).

\section{LEITMOTIFS: THE REALM OF NATURE}

\section{AND THE REALM OF THE GODS}

Some of the most recognized leitmotifs are simply associated with characters, situations, or objects-for example, Wotan's spear, which equals law and treaties, or the magic sword. But Wagner also sometimes links them together, so that, for instance, a melodic inversion matches an inversion in meaning, or an identical theme switched from minor to major suggests an otherwise hidden identity. Some examples from the Rheingold can give an idea of Wagner's use of repeating and transforming motifs.

The opera begins at the bottom of the river Rhine, in darkness, and we hear a rising series of notes.

Example 1: "Nature."

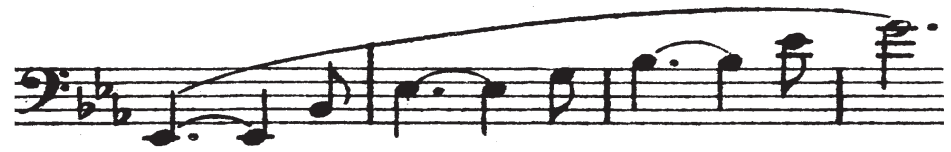

This theme recurs throughout the four operas, always associated with beginnings, with depths, and with nature, often more specifically with the Rhine.

But toward the end of the Rheingold, when it is clear that forces have been unleashed that will lead ultimately to the end of the world, this theme is reversed to produce the leitmotif "Twilight of the Gods."

18 Wagner (1851) 1888, 4:201. The published English translation loses the identity of the two uses of Ahnung. It reads: "These Melodic Moments-in which we remember a Foreboding, whilst they turn our Remembrance into a prophecy" ([1851] 1893, 347).

19 The role of emotion in myth and ritual is a point on which Lévi-Strauss was always reticent (see Leavitt 1984; 1996). 
Example 2: "Twilight of the Gods."

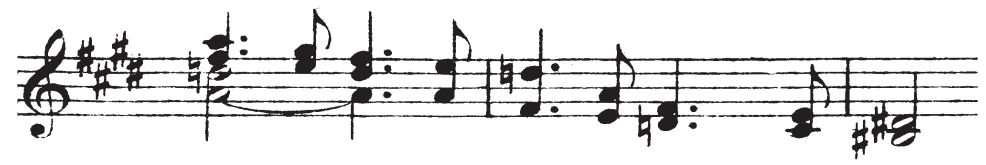

This is a fairly straightforward transformation. A more subtle one occurs between the first two scenes of the Rheingold. The sinister minor theme of the power of the ring, which is - we have been told explicitly-the terrifying power to dominate and control the world, requiring the renunciation of love, is heard during the scene change, moving gradually upward from the depths of the river to the mountaintops where the gods have built their new fortress, Valhalla. At the moment we first glimpse this luminous castle, the theme takes a major turn to become noble and majestic.

Example 3: "The Ring."

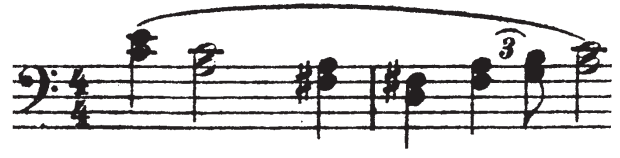

Example 4: "Valhalla."

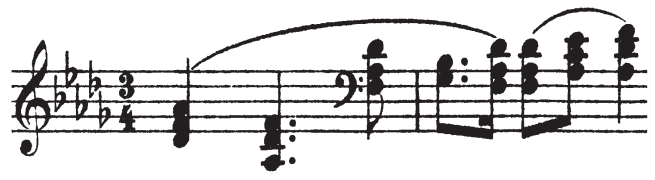

This new theme will recur every time reference is made not only to Valhalla itself, but also to the gods-as well as in less obvious situations in which the composer-storyteller wants to remind us of the gods or make some link to them. But it remains the case that this majestic theme is only the transformation of that of the baleful power of the ring: and this in itself suggests that the great weakness of the gods (which, at the same time, is also their strength) is the power that they wield over this world. In Arnold Whittall's words, "The motif associated with the ring, and with the world's wealth ... is transformed orchestrally into the Valhalla motif ..., a process leading the listener to connect Alberich's precious acquisition with Wotan's no less highly valued possession, and the power they both embody" (Whittall 2006, 157).

\section{HOW LÉVI-STRAUSS HELPS INTERPRET WAgNER: THE RENUNCIATION OF LOVE}

In his writings on the Ring, Lévi-Strauss dwelt primarily on the implications of a single motif, usually called "the Renunciation of Love." The motif first appears as sung by one of the Rhinemaidens to warn the lustful and greedy Alberich that while the Rheingold can give power over the whole world, it can do so only when cast into a ring, and the only person who can force the gold in this way is someone who has renounced love: "Only one who has refused the 
power of love [der Minne Macht], only one who drives away the pleasure of love [der Liebe Lust], he alone has the magic to force the gold into a circle."

Example 5: "Renunciation of Love."

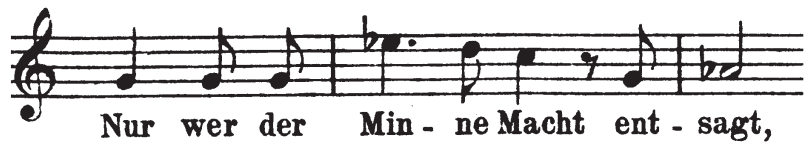

The Rhinemaidens think the gold is safe, presuming that no creature in the world would renounce love. But Alberich does: "Thus I curse love [die Liebe]!"

This theme recurs several times through the tetralogy. While it is usually labelled the "Renunciation of Love" motif, the theme serves primarily not to denote an abstract idea-Wagner himself did not give names to his motifsbut to suggest and recall a totality that is at once situational, conceptual, affective, and multi-sensorial. For every recurrence, at least in principle, the point is not to identify a tune that we can label the "Renunciation of Love" motif. On the contrary, we are meant to re-experience a subjective complex involving not only an abstract idea, but specific sensory images, situational feelings, and emotions: the renunciation, the forging of the ring, the desperation, frustration, and desire of Alberich - as well as the beginning of the world and the dark depths of the Rhine.

Sometimes the theme reappears during events that do not seem to have any direct association with Alberich or the ring. In his 1977 radio lectures for the CBC, Lévi-Strauss noted two of these events, respectively from Die Walküre and Götterdämmerung:

Here we have exactly the same problem as in mythology; that is, we have a theme-here a musical theme instead of a mythological theme-which appears at three different moments in a very long story ... What I would like to show is that the only way of understanding this mysterious reappearance of the theme is, although they seem very different, to put the ... events [marked by the theme] together, to pile them up one over the other, and to try to discover if they cannot be treated as one and the same event. (Lévi-Strauss 1978, 47-48)

I will not revisit this analysis here but will concentrate on yet another appearance of the motif, one discussed in Lévi-Strauss's "Note on the Tetralogy" ([1983] 1985, 236-37) and taken up again by Jean-Jacques Nattiez (2008, chap.6). It occurs in the argument between Wotan, the king of the gods, and his queen, Fricka, during scene 2 of the Rheingold - not long after the first appearance of the motif. In order to get Valhalla built, Wotan, who is the guarantor of all contracts, had made a bargain with the giants Fasolt and Fafner, who here appear as cosmic contractors. Wotan promised to reward them with his sister-inlaw, the goddess Freia, the guardian of the orchard that provides the gods the apples of immortality. Fricka is horrified by this treaty. She chides Wotan for his shortsightedness and readiness to bargain away the most precious things in the world. And it is during her vilification of her husband that, once again, we hear the theme of the renunciation of love. 
Why does this theme appear during this situation? The motif appears as support for the last four words of Fricka's line "For the vain toys of power and sovereignty, would you risk gambling love and woman's worth [Liebe und Weibes Wert]?" For Lévi-Strauss, Wotan's gamble represents a renunciation of love because Freia, in Norse mythology, is the goddess of love. The theme's presence here would suggest a parallel between Wotan, apparently the "good" king of the gods, and the "evil" dwarf Alberich: both are prepared to abandon love in order to gain power. Lévi-Strauss goes on to develop this parallel with other important thematic relationships to offer an outline structural analysis of the great themes of the opera. ${ }^{20}$

In his recent book on Lévi-Strauss, Nattiez (2008, chap. 6) challenges this interpretation on three counts. Two of his criticisms are specific and based on the text. He notes first that the motif in question does not occur as part of Wotan's speech, but of Fricka's $(2008,77)$. But this is hardly a major objection, given that motifs are meant to suggest themes and situations, not to label them: here the theme emerges at a moment when Fricka is chastising Wotan, and the reference is clearly to Wotan and his contract with the giants.

Beyond this, says Nattiez $(2008,77)$, the actual reference is not directly to love, but to "the value of love and of woman" (la valeur de l'amour et de la femme). It is true that this interpretation is found in French translations of the libretto, ${ }^{21}$ and it is a perfectly defensible translation. But "Liebe und Weibes Wert" is grammatically ambiguous: the feminine noun Liebe has the same form in the genitive and the accusative (as well as in the nominative). If Liebe were in the accusative rather than the genitive, then what is being renounced is not "the value of love and of woman," but rather "love and the value of woman." It is this interpretation that is found in at least some of the English translations of the libretto. ${ }^{22}$ I take this second interpretation to be more natural, especially given the clear echo it gives to Alberich's cry of renunciation: so verfluch' ich die Liebe! As Alberich cursed love, Wotan, in Fricka's words, is gambling love away. In both cases, love is lost explicitly in exchange for power, Macht. That he has shifted his central goal from love to power is clear at the beginning of Wotan's long autobiographical (autotheographical?) monologue in act 2, scene 2 of Die Walküre: Als junger Liebe Lust mir verblich, verlangt nach Macht mein Mut; "As young love's desire waned in me, my spirit longed for power."

Nattiez's third criticism (2008, 77, foreshadowed in Nattiez 1990, 277-78) opens up a wider theoretical debate. He challenges Lévi-Strauss's interpretation that the goddess Freia represents the emblem of love, noting that nowhere in the libretto is she explicitly given this function. More specifically, to interpret the risking of Freia as a renunciation of love, Lévi-Strauss must go outside the text itself to consider more broadly Freia's role in Norse mythology. This is a crucial point, since it is motivated by Nattiez's solidarity with the argument

20 This is presented in Lévi-Strauss (1983) 1985, and developed in Lévi-Strauss 1993.

21 This is the translation in d'Arièges 1968, 97, and in the unattributed French version in the Solti Rheingold (see in the Discography), 71.

22 See Armour 1911, 19, and the unattributed English translation in the Solti Rheingold (in the Discography), 70. 
of the sociologist Raymond Boudon (1968) that structuralism as a method is useful primarily for the analysis of closed systems, such as the phonology of a language, while open systems call for hermeneutic interpretation rather than structural analysis. In order for Lévi-Strauss to perform a structural analysis he must, then, treat Wagner's work as a closed universe and remain within its limits. An interpretation that reaches beyond the text of the operas is thus, by definition, illegitimate.

This critique would be perfectly appropriate for some forms of formalist analysis, such as the New Criticism of the 1950s and 1960s, for which the text is, precisely, a fixed and closed object. ${ }^{23}$ However, such criticism seems misdirected when its target is Lévi-Strauss's structuralism. Lévi-Strauss's model, Jakobson's structural linguistics, goes well beyond phonology: it also involves vocabulary, grammatical forms, and syntax, all of which are, to different degrees, open systems. And what about Jakobson's structural analyses of poetic texts, oral epics, and other forms of folklore? While Lévi-Strauss stresses Jakobson's phonology, this is not his only model: he draws on Jakobsonian structuralism much more broadly, and particularly, as I have already argued, on his poetics, the one area in which the two of them actually collaborated. ${ }^{24}$

Lévi-Strauss's major contribution was to draw on the rigor of linguistics, and not just of phonology, to propose new methods for dealing with open systems. To do this, one must not define the corpus a priori; the limits of the system are to be discovered by identifying recurring patterns. This is clear in his position, maintained from his first lectures on the subject (summaries in Lévi-Strauss [1984] 1987, 200-203) that a myth is made up of all of its variants, those to which the analyst has access, those to which he or she does not, and all those that will ever be told. For Lévi-Strauss, the myth consists of the ensemble of its versions, and since this ensemble is always by definition incomplete, and so open, we are led to consider the myth as an illimitable (indénombrable) ensemble that can be known only by approximation.

This openness is something that Lévi-Strauss shared with Wagner. The operas were composed for a given audience, members of a particular society, on the basis of materials that Wagner could justifiably expect his listeners to know: as Thomas Mann put it, Wagner used "parts of the long epic prehistory ([that] he could assume) were already familiar to his audience" (Mann [1963] 1985, 188). Wagner had immersed himself in the standard works on Norse mythology; he had every right to presume that an audience possessing the leisure and interest to spend some sixteen hours watching his opera would also possess a fundamental knowledge of Germanic myth. In this milieu, it was reasonable to expect the listener to know that Freia was the goddess of love-indeed, she is presented in one of the standard compilations, Jakob Grimm's Deutsche Mythologie as the northern Venus (Grimm 1835, 194, an equivalence that is maintained in the subsequent editions of this work). We cannot precisely define the

23 For classic examples of the method, see Brooks 1947, Wimsatt and Beardsley 1954.

24 The only essay co-authored by Jakobson and Lévi-Strauss is an analysis of the poem "Les chats" by Baudelaire (1962). 
limits of the encyclopedia of shared knowledge of this audience, but we can be sure that it included Freia as goddess of love (Cooke 1979, 154-55). ${ }^{25}$ Here a passage via Wagner can help make Lévi-Strauss's own work more explicit and understandable, and perhaps even offer it elements of a theory of reception.

The "renunciation" motif is associated, then, not only with Alberich, but also with Wotan. And since associations of this kind cannot be quantified or compared, or indeed, as Freud noted, negated ([1925] 1961), we could argue that it is associated equally with Wotan. Its recurrence says that the two are, in some crucial way, equivalent-specifically, that both have made the same choice: for power and against love. This choice is insistently and repetitively presented in the operas as the defining act of Alberich, turning him from a common garden dwarf into the central villain of the drama; and with the application of the motif to Wotan, it brings to light a kind of identity between the two. This relationship is suggested in Wotan's monologue from Die Walküre, which reveals that he chose power over love long before Alberich's appearance; it is made explicit in the first act of Siegfried, when Wotan calls Alberich "Schwarz-Alberich," Black Alberich, Alberich of Shadows, and calls himself "Licht-Alberich," Alberich of Light; and it is confirmed in the Norns' narrative at the beginning of Götterdämmerung, when we learn that Wotan's own power of contract, embodied in his spear, came out of an initial act of violence, the destruction of the world ash-tree (Abbate 1991, 175).

The parallel between Alberich and Wotan has been noted many times, among others by Lévi-Strauss ([1983] 1985, 237-38) and Nattiez $(2008,81)$ themselves. But beyond Wagner's operas, it raises one of the great themes of Norseand more broadly of Indo-European-mythology: the ultimate equivalence of gods and anti-gods. This is expressed in the Vedas (Lévi 1898) and was the theme of Georges Dumézil's first book, Le festin d'immortalité (1924). In the great struggle for control of the universe, the gods and their rivals, the antigods (titans, giants, asuras, and demons) are fundamentally the same. The difference is that one group has won the battle for immortality, while the other has lost-and the victory is not the result of some innate superiority of the winning side. Wotan is Alberich: both are driven by the desire for power.

One element that Wagner introduces that is not found directly in old mythologies is the possibility of escaping from this whole mechanism of power, of redemption through love. This idea may be derived from Christianity. But it is clear on the one hand that one of Wagner's great influences beginning from the late 1850 s was the philosopher Arthur Schopenhauer; and on the other that both Wagner and Schopenhauer were inspired by their discovery of Hindu and Buddhist thought. In an 1856 draft of the Ring, Brünnhilde, who will be the instrument for the destruction of the old world and creation of the new, explicitly refers to the doctrine of reincarnation. She says that while ordinary people will have to go through many more lives, she is now free from rebirth. ${ }^{26}$

25 Wilhelm Wägner's popularization of Norse mythology calls Freia "the goddess of beauty and love" ([1882] 1886, 209).

26 From a sketch for the opera cited in Nattiez 1983, 50. 
In a letter that year, Wagner proposes a new final speech for Brünnhilde that clearly refers to this conception:

From the land of desire I depart,

the land of illusion I flee for ever;

the open gates

of eternal becoming

I close behind me:

to the desire-free, illusion-free

holiest chosen land,

the goal of world-wandering,

redeemed from rebirth,

she who understands now departs. ${ }^{27}$

The Hindu and Buddhist references here are evident. Historically, both religions represented attempts to get beyond the old Vedic, and, as Jean Varenne argues (Varenne [1981] 1991, 237), Indo-European mechanism of sacrifice. What Wagner may be proposing in this version of the Ring is a kind of Germanic Upanishad, an alternative non-Christian, or non-directly Christian model of personal and cosmic salvation drawn out of Germanic pagan materials.

Recognizing Alberich and Wotan as different only in valence, and not in essence, is to put into question the "goodness" of the gods and the ultimate value of the whole god-run mechanism of the universe. The Germanic mechanism worked fundamentally like the Vedic one, and like other old Indo-European cosmoi. In the Indian case it came to involve reincarnation, and the cosmic cycle was put into question in the Upanishads and in Buddhism, which offered as an ultimate goal an escape from the repeating wheel of the world. There are clear parallels to this perspective in at least some stages of the development of the Ring. What is important for us is that this entire set of parallels depends on the identification of Wotan and Alberich: while he was certainly not the first to observe this identity, Lévi-Strauss's structural method allows it to be named clearly and in its specificity through his rigorous following-out of the theme of the "Renunciation of Love."

One can continue to discuss the relative merits of different interpretations of this motif. Yet the very fact that such a discussion can be undertaken, that one can raise the question of the role of the repetition of a musical theme in the unfolding of a narrative line, as well as ask what a recurring theme recalls and

27 Translation in Cooke 1979, frontispiece. The German reads:

Aus Wunschheim zieh' ich fort,

Wahnheim flieh' ich auf immer;

des ew'gen Werdens

off'ne Thore

schliesz' ich hinter mir zu:

nach dem wünsch- und wahnlos

heiligstem Wahlland

der Welt-Wanderung Ziel,

von Wiedergeburt erlös't

zieht nun die Wissende hin. 
what it foreshadows, must presuppose a parallel between Wagner's process of synthesis and Lévi-Strauss's process of analysis.

One possibility, then, is to offer analyses of the Ring using a Lévi-Straussian method-something represented by Lévi-Strauss's own efforts, those of Carl Dahlhaus (e.g., [1986] 1988), and the alternatives proposed by Nattiez. What I want to insist on here, however, is the possibility that Wagner composed his works in a way that, following an intaglio reading of Lévi-Strauss, parallels that of myth-tellers themselves.

As a kind of summary, Nattiez cites a page of Wagner (from 1871) that sounds remarkably like Lévi-Strauss. He concludes (Nattiez 2008, 192) that this "shows not that Wagner is a precursor of structuralism, but that Lévi-Strauss is a Romantic." ${ }^{28}$ Yet the parallel between Wagner and Lévi-Strauss is far more specific than what might be their shared Romanticism: what makes Wagner unique among the Romantics is his elaboration of a distinctive compositional method that corresponds to what Lévi-Strauss felt must have been that of the composers of myths.

\section{HoW LÉvi-STRAUSS MIGHT HELP INTERPRET WAgNER: MOTIFS AND PROTO-MOTIFS}

Wagner's compositional method closely associates a repeating idea or emotion with a repeating musical theme. Learning to hear his compositions was clearly, for him, a process of the formation of the ear and mind through listening and watching. As against this, it soon became common practice for Wagnerians to memorize a list of named motifs that could then be identified. ${ }^{29}$ Such a practice presumes that the music of the Ring can be divided into two parts: first, clearly identified leitmotifs, which can be expected to appear mechanically in association with a name or other verbal formula, and second, "the rest of the music," presumably including the kind of material more familiar to opera-goers. $3^{\circ}$

The possibility that Wagner's process of composition was somehow "like" that of the intergenerational transmission and transformation of myths raises the question of the thoroughness of the motif-composition; how much repetitive but apparently non-motif-motivated music should be read as potential motif? The Ring is a finished work, although one achieved through a long history of transformations. Yet as we have seen, a myth, at least for Lévi-Strauss, is never

\footnotetext{
28 Nattiez makes a similar argument in 1990, 268, 285.

29 It was not Wagner, but Hans von Wolzogen (1876) who produced the first catalogue of motifs for the Ring.

30 The Ring does include relatively self-contained pieces that stand out from the overall woven motif-texture and resemble arias and recitatives from classical opera. In her discussion of the role of narrative within opera, Abbate (1991, chap. 5) analyzes one such piece, Wotan's long monologue in act 2 of Die Walküre. While parts of the monologue include leitmotifs, it has a more general structure of its own, a more abstract musical development that does not index particular images, but creates, repeats, and transforms an overall mood. Something comparable is found the Homeric poems, which also show relatively self-contained developments, often extended similes. Such "lyric epiphanies" (Friedrich 2001) seem to be more independently crafted than the surrounding text, carrying a lower formulaic load; however, they do seem to be coming out of the same treasury of collective diction and themes.
} 
contained in a closed corpus but involves all of its real and potential variants. What if we were to imagine an ongoing tradition of Ring composition, on the model of mythic form as developed through collective transmission? Mythic composition goes "all the way down," with no distinction between form and content: the tale-teller does not start out with a moral in mind, for which he or she then finds characters and incidents. All develop together, always as a transformation of pre-existing material. And if we consider seriously the idea that Wagner is acting in the same way as traditional mythmakers, then the sharp division between what is and is not motif becomes problematic. Apparently transitional or abstract music may carry the seeds of full-fledged motifs.

Carolyn Abbate makes a similar argument regarding what she sees as musical repetition having nothing to do with motifs (which she refers to as "repetition without verbal pretext"). In two widely spaced moments in Wotan's monologue in act 2, scene 2 of Die Walküre, he sings "a particular vocal fragment, set over an inverted E minor chord" (Abbate 1991, 188), first in retelling the emergence of Alberich, later in referring to the giant Fafner (see Examples 6 and 7 ).

Example 6.

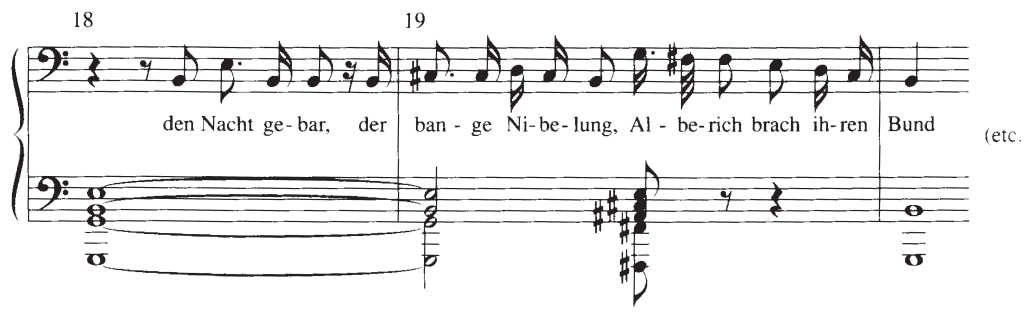

Example 7 .

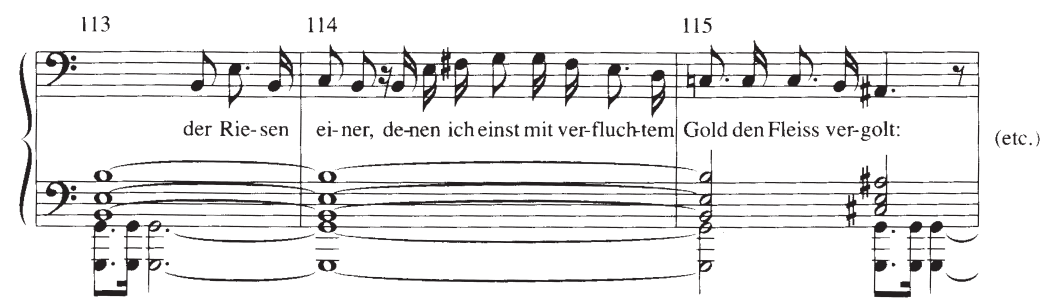

There is a return of both the intoned, recitative-like texture of the monologue's opening, and of a specific musical idea ... The recurring musical element is not a leitmotif, and its repetition is not engendered by some textual signal ... The musical repetitions are independent of the text's details. In the case of the inverted E minor chord, the vocal filip for "den Nacht gebar, der bange Niblung" and "der Riesen einer," one would be led into specious contrivances indeed in attempting explain the repetition in terms of these specific words (what do Alberich and Fafner have in common?). (Abbate 1991, 188-89) 
What Alberich and Fafner have in common is the Ring! ${ }^{31}$ This "musical idea" occurs as Wotan is about to tell of Alberich's seizing the Gold and forging the Ring; and it reoccurs at the moment Wotan is about to tell of Fafner's seizing the Ring from his brother, and then forecast that he, Wotan, will have to seize it from Fafner. Now this particular "musical idea" does not, as far as I know, come back again in the Ring cycle, so it can hardly be called a leitmotif. But it certainly does show the basic pattern of linkage of specific idea and image and specific musical form.

We can imagine that in the mouth of a myth-teller-or if Wagner, like Homer, had really represented a multi-generational tradition-such an embryonic idea might develop into a full-fledged theme. And such a view might support an argument for those who are willing to try out what might not always be such "specious contrivances," in order to judge the extent of motif-composition in Wagner's work.

\section{HOW WAgNER HELPS INTERPRET LÉvi-STRAUSS: MYTHEME AND PARA-MYTHEME}

In Lévi-Strauss's first publication on myth, written in English for an American symposium, he sought to identify "constituent units," which would parallel, but exist at a higher level than-that is, include - the levels of phoneme, morpheme, and what he calls semanteme. These "gross constituent units," then, are to be sought "on the sentence level" (Lévi-Strauss 1955, 86, para. 3.1); each such unit "will consist in a relation" (87, para. 3.3). In his French version published in 1958, and in the subsequent English translation from the French, he calls these gross constituent units mythemes $(1958,233 ; 1963,207)$, a term evidently coined to parallel the linguistic terms phoneme, the minimal distinctive sound-unit of a language, and morpheme, the minimal unit bearing meaning. A mytheme would, analogously, be the minimal unit bearing a mythic meaning. As the suffix -eme indicates in these cases, it would be a relatively abstract concept that can be realized in different concrete forms, as a phoneme can be realized in different allophones, a morpheme in different allomorphs. ${ }^{22}$

So far things seem clear: mythemes or gross constituent units exist on a level where each can be represented as a sentence $(1955,86$, para. 3.1; 1958, 233; 1963, 207). This is because each of them "will consist of a relation." 33 Yet shortly hereafter, Lévi-Strauss changes his definition, claiming that "the true constituent units of the myth" are, rather, "bundles," groups or packets or columns, of such relations having something in common (1955, 87, para. 3.4; 1958, 233-34; 1963, 207). Here Lévi-Strauss does not use the term mytheme. ${ }^{44}$ Further, he

31 In a review of Abbate's book, Christopher Wintle notes that these two moments both express "the comparable dismay in which Wotan views both Alberich and Fafner as agents standing in the way of his own achievements" (Wintle 1993, 126).

32 As far as I am aware, neither Lévi-Strauss nor anyone else has gone so far as to label such realizations as allomyths.

33 The French reads that a mytheme "a la nature d'une relation."

34 The term is used only once more in the article, and in a remarkably ambiguous manner. LéviStrauss $(1958,235-36 ; 1963,209-10)$ proposes laying out a myth as a series of relations or incidents and 
maintains this ambiguity in later writings, and his commentators have been divided on whether to take the mytheme as a single relation representable by a sentence or a bundle of such relations. 35

We have seen that what matters for Lévi-Strauss is "the story being told," not the way the story is told. So a mytheme, whether a relation or a bundle of relations, is a semantic unit, an image or incident, that is, an element of referential content, that should never be confused with its form or its aesthetic or ritual or musical presentation. The same myth can be told in any language, in a virtually unlimited number of phrasings, styles, and even semiotic modalities. "Myth is the part of language," he writes, "in which the formula traduttore traditore reaches its lowest truth value" (1963, 206; cf. 1955, 85; 1958, 232). The result of this argument is that Lévi-Strauss based most of his analyses on his own summaries of mythic narratives, or sometimes merely on what he considered the essential point of the myth, rather than on the texts themselves-whether in translation or in the original language-or on actual performances. He has often been criticized for this, particularly by practitioners of ethnopoetics such as Dell Hymes (e.g., 1981; 1985) and Dennis Tedlock (1983, 206-207). LéviStrauss, for his part ([1971] 1981, 631-33; 1987), has responded to such criticism by trying to demonstrate the breadth and richness of what can be learned by focusing on referential content.

It is clear, in any case, that a poetic repetition, a rhyme or alliteration or repeating word or formula, does not in itself constitute a mytheme and plays no part in standard Lévi-Straussian myth analysis. If he had been completely consistent, in other words, Lévi-Strauss should have been content to look at a synopsis of the Ring, without considering the libretto more closely, or indeed

giving a number to each type of incident-for example, to tabulate each time a hero kills a monster. This produces "a sequence of the type $1,2,4,7,8,2,3,4,6,8,1 \ldots$ " and so forth. The next task is to break up the linear order of the narrative into two dimensions, creating columns of incidents bearing the same number. Once this has been done, we should "successively try different arrangements of the mythemes until we come across one that satisfies the conditions enumerated on page 233" (1958, 236, my translation). Unfortunately, page 233 is where both definitions of mythemes are to be found. Is each numbered item a mytheme, then, or each column of numbers? The text can, perhaps, be more easily read as the latter, but the former remains a real possibility, and the first, English, version, in fact, would tend toward the reading of the mytheme as single relation. After presenting the twodimensional columns of numbers, Lévi-Strauss writes, "We will attempt to perform the same kind of operation [i.e., the operation of moving a line of numbers into columns] on the Oedipus myth, trying out several dispositions until we find one which is in harmony with the principles enumerated under 3.1 " (1955, 88). Now paragraph 3.1 in this first version of the article is the one in which the gross constituent units are said to be on the sentence level, and the principles are not the specifics of arranging bundles (that is in 3.4), but general principles of "any kind of structural analysis."

35 A quick survey finds the mytheme as a single relation representable as a sentence in MarcLipiansky 1973, 189-91; Vernant (1974) 1980, 225; Leavitt 2005 (and this usage has been confirmed in personal communications from Pierre Maranda and Robert Crépeau), and, it appears, in Lévi-Strauss (1976) 1985, 144-46. On the other hand, mythemes are taken to be bundles of relations in Hawkes 1977, 44; Csapo 2005, 220-23; Nattiez 2008, 50-51; and apparently in Lévi-Strauss (1971) 1981. The structuralist film analyst Christian Metz $(1964,86)$ distinguishes between "mythèmes" and what he calls "grands mythèmes." 
the music. That he fails to follow his own strictures in considering Wagner only, to my mind, strengthens his argument. ${ }^{36}$

Wagner's theory and practice remind us that sometimes the setting and poetic form of the text, the words chosen, their arrangement, and their rhythmic and melodic presentation, provide clues for interpreting content. When an oral poet of the central Himalayas elaborates at length on the scene in which his hero abandons his country, and his weeping mother asks him, "Why are you leaving your kingdom? Why are you leaving the stable of the horses? Why are you leaving the stable of the elephants? Why are you leaving Kusumā the grass-cutting girl? Why are you leaving Lachimà the cat? Why are you leaving your mother?," this long elaboration in itself is a sign of the importance of this moment in the narrative's development. Later, when his lover asks him the same question in the same words, the parallel between the two situations is made absolutely evident (Leavitt 1996). If one were to restrict our focus only to the libretto of the Rheingold, the fact that Fricka berates Wotan in words that recall Alberich's renunciation of love clearly points to the parallel between the two situations. In these cases, the poetics of the narrative and the way that it is presented guide its interpretation. What is it that is repeated? Which moment of the narrative will take the form of a joke, a pun, or a riddle?

Without being mythemes in themselves, Wagner's motifs, like poetic repetitions, serve as indicators of mythemes, as para-mythemes. The Grundthemen operate alongside the narrative, comment upon it, and above all guide the listener's response to the narrated events. Lévi-Strauss himself recognizes this process when he writes that "it takes a counterpoint between poem and music to make [a] formulation explicit" ([1983] 1985, 237). In Wagner's words, repeating and transforming motifs function as "guides-to Feeling," literally "indicators of the road of feeling" (Gefühlswegweisern) "through the whole labyrinthine [vielgewundenen] construction of the drama" ([1851] 1888, 249; [1851] 1893, 346).

Such guiding material may take up large parts of a performance. It is not only poetic or musical elements that can serve as para-mythemes. In the case, for example, of the Sanskrit epic the Mahäbhärata, Western commentators have been struck for over a century by the epic's extraordinary length and the slow pace of much of its narrative. In an often-cited characterization, Hermann Oldenberg $(1922,1)$ called the Mahäbhärata a "monstrous chaos." More diplomatically, in his introduction to a recent (partial) translation of the epic, John D. Smith notes its "willingness to embrace all manner of 'extra' material" (2009, li) and asks, "Allowing that the narrative does always end up on course, why does it so often seem to choose the most meandering route available?" (2009, 1). The epic's inordinate length and slowness are due, in part, to a tendency to tell stories inside stories inside stories and to explain a situation by telling the story that led up to it, but also to the epic characters' constant tendency to devote

36 This is not the only time Lévi-Strauss is admirably inconsistent. His very analysis of Oedipus, the model for all that will follow, draws not only on the doings of the protagonists, but on the meanings of their names: one whole column of his four-column analysis consists of the interpretations of their names as "left-handed," "limping," "swell-foot" (Lévi-Strauss 1955, 89-91; 1958, 236-39; 1963, 214 ff.). 
themselves to discussions of the relative value of alternative actions and to giving out religious teachings in the middle of a battle or a love scene. The longest such sermon is that of the dying hero Bhișma, who, in the words of J. A. B. van Buitenen (1973, xxiii), "interminably expounds on the varieties of dharma in what must be the longest deathbed sermon on record." But the most celebrated is, evidently, the Bhagavad Gìtā (Mahäbhärata, bk. 6, chaps. 23-40), arguably the best-known Hindu religious text, and which in its epic context greatly delays the beginning of the climactic battle. The fact that bad guys are as given to preaching as are good guys may be one sign that the Mahäbhärata is an epic rendition of the great battles between gods and demons discussed above (as argued in Dumézil 1968).

These long digressions have often been treated by Western scholars as mere encumbrances, without narrative justification. Textual analyses usually take them to be later accretions to a primordial clear and straightforward story, an Ur-Mahābhārata, whose submerged outline can still be glimpsed beneath the heaps of tale-telling and pious verbiage. Yet there is no real evidence that these philosophical discourses are any more recent than the narrative parts of the epic. Might they not be serving, in fact, as para-mythemes, indicators, or guides for the interpretation of the narrative?37

One also encounters similar complaints about how the length and repetitiveness of some of Wagner's "interminable recitative" 38 slow down the narrative movement. And the stages of composition of the Ring, as it is usually presented, show parallels to the usual picture of the composition of the Mahäbhärata through accretion and incorporation of extraneous material. Wagner appears to have begun with a straightforward story, which then expanded backwards and outwards (Dahlhaus [1971] 1979), involving all kinds of "migrations, accretions, tales engendering other tales" (Abbate 1991, 164). Some scholars, such as Abbate, have defended the recitatives as operating major transformations in the movement of the story; and like the philosophical speeches in the Mahābhärata, they are not always told by reliable narrators. More broadly, might not this very cumbersomeness, in both cases, be understood as richness, an ongoing commentary guiding interpretation, that is, as narrative and philosophical leitmotifs?

\section{Conclusion}

If Lévi-Strauss saw Wagner as a precursor, I argue, he did so with good reason. I have suggested some ways in which these two thinkers, and myth and music, might illuminate each other; why, conversely, Wagner, too, might have

37 The most prominent exponent of this view was Madeleine Biardeau. As she put her position, "In spite of all that has been claimed, it is impossible to be satisfied with a simple juxtaposition of an epic narrative with didactic passages, nor to see such passages as later additions ... An attentive familiarity with the text shows a congruence between the meaning or meanings of the narrative and the theoretical discourses which help in deciphering its different semantic levels" (Biardeau 1985, 27-28). Her global reading of the epic will be found in Biardeau 2002.

38 The phrase is given, in quotes, in a recent essay by David Goldman (2010). Just how much of a commonplace it has become can be gathered both from the essay and from the ensuing discussion. 
seen, or at least Wagnerians might see, Lévi-Strauss as a parallel thinker in other modalities-not because both were Romantics, but because both were structuralists.

For students of myth, the comparison suggests that it will not be enough merely to follow Lévi-Strauss's explicit model, or even to criticize it, but that what is called for is to step back to rediscover and re-explore his own sources of inspiration: to reconsider the lessons offered by Jakobson, evidently, and by his entire body of work, his linguistics, philology, and folkloristics, and not only his phonology; and more globally to draw on the whole of linguistics, which is far from having rendered all its possible services as a model; and, as LéviStrauss himself insisted, to reconsider the lessons offered by music. What LéviStrauss found in Wagner was not only a mythmaker, but a sometimes explicit, sometimes implicit theoretician of musico-mythopoetic practice.

\section{REFERENCES}

Abbate, Carolyn. 1991. Unsung Voices: Opera and Musical Narrative in the Nineteenth Century. Princeton: Princeton University Press.

Armour, Margaret, trans. 1911. Richard Wagner, The Rhinegold and the Valkyrie. London: Heinemann.

Biardeau, Madeleine. 1985. "Introduction." In Le Mahābhārata, edited by Madeleine Biardeau, vol. 1, 15-43. Paris: Flammarion.

-2002. Le Mahābhārata: Un récit fondateur du brahmanisme et son interprétation. 2 vols. Paris: Seuil.

Boudon, Raymond. 1968. A quoi sert la notion de structure dans les sciences humaines? Paris: Gallimard.

Brooks, Cleanth. 1947. The Well-Wrought Urn: Studies in the Structure of Poetry. New York: Harcourt Brace.

Coeuroy, André. 1965. Wagner et l'esprit romantique: Wagner et la France, le wagnérisme littéraire. Paris: Gallimard.

Cooke, Deryck. 1979. I Saw the World End: A Study of Wagner's Ring. London: Oxford University Press.

Cord, William O. 1990. The Teutonic Mythology of Richard Wagner's The Ring of the Nibelungs. Vol. 1. Studies in the History and Interpretation of Music, 16. Lewiston, ME: Edwin Mellen.

Csapo, Eric. 2005. Theories of Mythology. Oxford: Blackwell.

Dahlhaus, Carl. (1971) 1979. Richard Wagner's Music Dramas. Translated by Mary Whittall. Cambridge: Cambridge University Press. . (1986) 1988. "Analyse des Mythos: Claude Lévi-Strauss und 'Der Ring des Nibelungen.' In Klassische und romantische Musikästhetik, 458-67. Laaber: Laaber-Verlag.

d'Arièges, Jean, trans. 1968. Richard Wagner, L'or du Rhin. Paris: Aubier Flammarion.

Dumézil, Georges. 1924. Le festin d'immortalité: Étude de mythologie indoeuropéenne. Annales du Musée Guimet, Bibliothèque d'Etudes, 34. Paris: Geuthner. 
1968. Myth et épopée I: L'idéologie des trois fonctions dans les épopées des peuples indo-européens. Paris: Gallimard.

Freud, Sigmund. (1925) 1961. "Negation." Translated by Joan Riviere and James Strachey. In Standard Edition of the Complete Works of Sigmund Freud, edited by James Strachey, vol. 19, 233-39. London: Hogarth.

Friedrich, Paul. 2001. "Lyric Epiphany." Language in Society 30:217-47.

—. 2006. "Maximizing Ethnopoetics." In Language, Culture, and Society, edited by Christine Jourdan and Kevin Tuite, 207-28. Studies in the Social and Cultural Foundations of Language, 23. Cambridge: Cambridge University Press.

Godefroid, Philippe. 1988. Richard Wagner: L'opéra de la fin du monde. Découvertes Gallimard, 39. Paris: Gallimard.

Goldman, David P. 2010. "Why We Can't Hear Wagner's Music." First Things (December 1, 2010). <http://www.firstthings.com/article/2010/11/ why-we-cant-hear-wagnerrsquos-music $>$.

Grey, Thomas S. 2008. "Leitmotif, Temporality, and Musical Design in the Ring." In The Cambridge Companion to Wagner, edited by Thomas S. Grey, 85-114. Cambridge: Cambridge University Press.

Grimm, Jakob. 1835. Deutsche Mythologie. Göttingen: Dieterich.

Hawkes, Terence. 1977. Structuralism and Semiotics. London: Methuen.

Hymes, Dell. 1981. "In Vain I Tried to Tell You": Essays in Native American Ethnopoetics. Philadelphia: University of Pennsylvania Press.

— 1985. "Language, Memory, and Selective Performance: Salmon's Tale as Twice Told to Boas." Journal of American Folklore 98:391-434.

Jakobson, Roman. 1960. "Linguistics and Poetics." In Style in Language, edited by Thomas E. Sebeok, 350-77. Cambridge, MA: MIT Press.

Jakobson, Roman, and Claude Lévi-Strauss. 1962. "Les chats' de Charles Baudelaire." L'Homme 2 (1):5-21.

Leavitt, John. 1984. "Structure et émotion dans un rite kumaoni, Himalaya central." Culture 4:19-31.

_ 1996. "Meaning and Feeling in the Anthropology of Emotions." American Ethnologist 23:514-39.

- 2005. "Les structuralismes et les mythes." Anthropologie et Sociétés 29 (2):45-67.

Lévi, Sylvain. 1898. La doctrine du sacrifice dans les Brâhmanas. Bibliothèque de l'Ecole Pratique des Hautes Études, Section des Sciences Religieuses, 11. Paris: E. Leroux.

Lévi-Strauss, Claude. 1955. “The Structural Study of Myth.” In Myth: A Symposium, edited by Thomas E. Sebeok, 428-44. Bloomington: Indiana University Press.

. 1958. Anthropologie structurale. Paris: Plon.

- (1958) 1976. "The Story of Asdiwal." In Structural Anthropology Two, translated by Monique Layton, 146-97. New York: Basic Books. 1962. La pensée sauvage. Paris: Plon. -1963. Structural Anthropology. Translated by Claire Jacobson and Brooke Grundfest Schoepf. New York: Basic Books. 
1964. Le cru et le cuit. Mythologiques, 1. Paris: Plon.

. (1964) 1969. The Raw and the Cooked. Translated by John and Doreen Weightman. Introduction to a Science of Mythology, 1. New York: Harper and Row.

- (1971) 1981. The Naked Man. Translated by John and Doreen Weightman Introduction to a Science of Mythology, 4. New York: Harper and Row.

- (1976) 1985. "The Lessons of Linguistics." In The View from Afar, translated by Joachim Neugroschel and Phoebe Hess, 138-47. Oxford: Blackwell. .1978. Myth and Meaning. Toronto: University of Toronto Press.

- (1983) 1985. "A Note on the Tetralogy." In The View from Afar, translated

by Joachim Neugroschel and Phoebe Hess, 235-39. Oxford: Blackwell.

- (1984) 1987. Anthropology and Myth. Translated by Roy Willis. Oxford: Blackwell.

_ 1987. "De la fidélité au texte." L’Homme 101:117-40.

_.1993. "Mythe et musique." Magazine littéraire 311:39-45.

Mann, Thomas. (1963) 1985. Pro and Contra Wagner. Translated by Allan Blunden. Chicago: University of Chicago Press.

Marc-Lipiansky, Mireille. 1973. Le structuralisme de Lévi-Strauss. Paris: Plon.

Metz, Christian. 1964. "Le cinéma: langue ou langage?" Communications 4:52-90.

Nattiez, Jean-Jacques. 1983. Tétralogies. Wagner, Boulez, Chéreau: essai sur l'infidélité. Paris: Christian Bourgois.

—. (1984) 1989. Proust as Musician. Translated by Derrick Puffett. Cambridge: Cambridge University Press.

. 1990. Wagner androgyne: Essai sur l'interprétation. Paris: Christian Bourgois.

-2008. Lévi-Strauss musicien: Essai sur la tentation homologique. Paris: Actes Sud.

Oldenberg, Hermann. 1922. Das Mahabharata: seine Entstehung, sein Inhalt, seine Forschung. Göttingen: Vandenhoeck \& Ruprecht.

Shaw, George Bernard. 1898. The Perfect Wagnerite: A Commentary on the Ring of the Niblungs. London: G. Richards.

Smith, John D., ed. and trans. 2009. The Mahābhärata. London: Penguin.

Tedlock, Dennis. 1983. The Spoken Word and the Work of Interpretation. Philadelphia: University of Pennsylvania Press.

Thorau, Christian. 2009. "Guides for Wagnerites: Leitmotifs and Wagnerian Listening." In Richard Wagner and His World, edited by Thomas S. Grey, 133-50. Princeton: Princeton University Press.Twain, Mark. (1891) 1917. "At the Shrine of Saint Wagner." In "What Is Man?" and Other Essays, 180-93. New York: Harper and Sons.

van Buitenen, J. A. B., ed. and trans. 1973. The Mahäbhärata. Vol. 1, The Book of the Beginning. Chicago: University of Chicago Press.

Varenne, Jean. (1981) 1991. "The Indo-Europeans," translated by John Leavitt. In Mythologies, edited by Yves Bonnefoy, 1:233-39. Chicago: University of Chicago Press. 
Vernant, Jean-Pierre. (1974) 1980. “The Reason of Myth." In Myth and Society in Ancient Greece, trans. Janet Lloyed, 186-242. London: Methuen.

Wagner, Richard. (1851) 1888. Oper und Drama. Richard Wagner, Gesammelte Schriften und Dichtungen, vols. 3-4. Leipzig: E. W. Fritzsch.

. (1851) 1893. Opera and Drama. Translated by William Ashton Ellis. Vol.2 of Richard Wagner's Prose Works. London: Kegan, Paul, Trench, Trübner.

—. (1856) 1872. "Sketch for the Ring." In Gesammelte Schriften und Dichtungen 4:362-363.

Wägner, Wilhelm. (1882) 1886. Asgard and the Gods. Translated by M. W. Macdowall. 3 rd ed. London: Swan Sonnenschein. (First German edition, 1874.) Whittall, Arnold. 2006. "Leitmotif." In The New Grove Guide to Wagner and His Operas, edited by Barry Millington, 153-60. Oxford: Oxford University Press.

Wimsatt, W. K., and Monroe Beardsley. 1954. The Verbal Icon: Studies in the Meaning of Poetry. Lexington: University of Kentucky Press.

Wintle, Christopher. 1993. "Wotan's Rhetoric of Anguish." Journal of the Royal Musical Association 118:121-43.

Wolzogen, Hans von. 1876. Thematischer Leitfaden durch die Musik zu Rich. Wagner's Festspiel Der Ring des Nibelungen. Leipzig: Edwin Schloemp.

\title{
DISCOGRAPHY
}

Wagner, Richard. Das Rheingold. George Solti, conductor. London Records 414 101.

\begin{abstract}
Starting with Claude Lévi-Strauss's evaluation of Richard Wagner as "the undeniable father of the structural analysis of myth," this paper compares Lévi-Strauss's myth analysis with Wagner's myth construction, arguing that each illuminates, clarifies, and potentially enriches the other.
\end{abstract}

\section{RÉSUMÉ}

Claude Lévi-Strauss voyait en Richard Wagner «le père irrécusable de l'analyse structurale des mythes». Partant de cette évaluation, cet article compare l'analyse des mythes de Lévi-Strauss à la construction des mythes de Wagner, faisant valoir que l'une éclaire, précise et enrichit potentiellement l'autre. 